\title{
QUEEN'S
UNIVERSITY
BELFAST
}

\section{From Francis Hutcheson to James McCosh: Irish Presbyterians and Defining the Scottish Philosophy in the Nineteenth Century}

Holmes, A. R. (2014). From Francis Hutcheson to James McCosh: Irish Presbyterians and Defining the Scottish Philosophy in the Nineteenth Century. History of European Ideas, 40(5), 622-643.

https://doi.org/10.1080/01916599.2013.851991

Published in:

History of European Ideas

Document Version:

Peer reviewed version

Queen's University Belfast - Research Portal:

Link to publication record in Queen's University Belfast Research Portal

\section{Publisher rights}

Copyright 2013 Taylor \& Francis.

This is an accepted manuscript of an article published by Taylor \& Francis Group in History of European Ideas on 8/11/2013, available online: http://www.tandfonline.com/10.1080/01916599.2013.851991.

\section{General rights}

Copyright for the publications made accessible via the Queen's University Belfast Research Portal is retained by the author(s) and / or other copyright owners and it is a condition of accessing these publications that users recognise and abide by the legal requirements associated with these rights.

Take down policy

The Research Portal is Queen's institutional repository that provides access to Queen's research output. Every effort has been made to ensure that content in the Research Portal does not infringe any person's rights, or applicable UK laws. If you discover content in the Research Portal that you believe breaches copyright or violates any law, please contact openaccess@qub.ac.uk. 
From Francis Hutcheson to James McCosh: Irish Presbyterians and defining the Scottish Philosophy in the nineteenth century

Dr Andrew R. Holmes

Lecturer in Modern Irish History

School of History and Anthropology

Queen’s University Belfast

BT7 1NN

Telephone: 02890971297

Email: a.holmes@qub.ac.uk

Abstract

This article examines the disputes amongst Irish Presbyterians about the teaching of moral philosophy by Professor John Ferrie in the college department of the Royal Belfast Academical Institution in the early nineteenth century and the substantive philosophical and theological issues that were raised. These issues have largely been ignored by Irish historians, but a discussion of them is of general relevance to historians of ideas as they illuminate a series of broader questions about the definition and development of Scottish philosophy. These are represented in the move from two philosophers who had strong connections with Irish Presbyterianism - Francis Hutcheson, the early eighteenth-century moral sense philosopher and theological moderate from County Down, and James McCosh, nineteenthcentury exponent of modified Common Sense philosophy at Queen's College Belfast and a committed evangelical. In particular, this article addresses three important themes - the definition and character of 'the Scottish philosophy', the relationship between evangelicalism and Common Sense philosophy, and the process of development and adaptation that occurred to eighteenth-century Scottish thought during the first half of the nineteenth century.

Keywords

Scottish Philosophy, Common Sense, evangelicalism, Presbyterianism, Ireland, John Ferrie 
From Francis Hutcheson to James McCosh: Irish Presbyterians and defining the Scottish Philosophy in the nineteenth century*

Both the founder and one of the first chroniclers of a distinctive Scottish philosophy had significant links with Presbyterians in the north of Ireland. Francis Hutcheson, 'the father of the Scottish Enlightenment', was born in County Down in 1694. ${ }^{1}$ Hutcheson's father was a Presbyterian clergyman in Ulster and Francis too trained to be a minister before becoming a tutor in Dublin and then professor of moral philosophy at Glasgow University in 1730. James McCosh was born in Ayrshire in 1811 and became a Free Church of Scotland clergyman. ${ }^{2}$ McCosh gained eminence as a religious and philosophical writer during his tenure as professor of logic and metaphysics at Queen’s College, Belfast from 1851 to 1868 and was a prominent member of the General Assembly of the Presbyterian Church in Ireland. He left Belfast to become the president of the College of New Jersey where he was largely responsible for the development of modern-day Princeton University. In addition to his attempt to reconcile evangelical religion and evolutionary science, McCosh was also one of the first scholars to define a distinctive Scottish philosophical tradition in his 1875 work, The Scottish Philosophy, Biographical, Expository, Critical. From Hutcheson to Hamilton. Following McCosh, historians of the Scottish Enlightenment and Presbyterianism in Ulster have devoted considerable attention to Hutcheson, the impact he had on the development of moderate New Light religion amongst Irish Presbyterians, and how his classical republicanism informed political radicalism in the late eighteenth century. ${ }^{3}$ Unlike recent developments in Scottish historiography, however, there has been virtually no attention paid to the relationship in Ulster between Enlightenment thought and theological conservatives, especially evangelicals, or the fate of the Scottish philosophy in the nineteenth century. ${ }^{4}$

This article addresses these themes through a study of the appropriation and reinterpretation of Scottish philosophy by theologically-conservative Presbyterians in Ulster in the early nineteenth century. It concentrates on the disputes of that period that surrounded the teaching of moral philosophy by Professor John Ferrie in the college department of the Royal Belfast Academical Institution, which provided most Irish Presbyterian clergymen with their liberal arts education. Irish historians have described these clashes in terms of the baleful growth of evangelicalism and the vindictiveness of its Presbyterian leader Henry Cooke, the most notable Irish Presbyterian of the nineteenth century. Generally speaking, Cooke’s animus towards the Institution and Ferrie has been explained by his opposition to the influence of political and theological liberals involved in the administration and the faculty. ${ }^{5}$ This is undoubtedly part of the story, though Cooke's sincere religious motives for opposing Arian influence have too often been dismissed as a cloak for political concerns. ${ }^{6}$ 
Of more general relevance to historians of ideas are the substantive philosophical and theological issues raised by the Ferrie controversy and which have largely been glossed over by Irish historians. An examination of this case-study contributes to a series of broader questions about the definition and development of Scottish philosophy. These are reflected in the move from the moral-sense philosophy of the theologically-moderate Francis Hutcheson to the Common Sense epistemology of the evangelical James McCosh. In particular, this article addresses three important topics - the meaning and character of 'the Scottish philosophy', the relationship between evangelicalism and Common Sense philosophy, and the process of development and adaptation that occurred to eighteenth-century Scottish thought in the first half of the nineteenth century.

First, an examination of Irish Presbyterians and Scottish thought raises a fundamental issue of definition - what was 'the Scottish philosophy'? ${ }^{7}$ Hutcheson and McCosh represent different emphases within that tradition and how it changed over time. Crudely speaking, Scottish philosophers during the eighteenth century were best known for their desire to improve society by inculcating moral and social virtue, a concern that began with Hutcheson and found expression in the writings of, amongst others, Adam Smith and Adam Ferguson. By contrast, as Gordon Graham notes, Scottish thinkers in the nineteenth century increasingly gravitated away from the science of society towards the study of logic and perception. ${ }^{8}$ In this new context, the eighteenth-century debate between David Hume and Thomas Reid on this issue gained renewed prominence. Both Hume and Reid were united in prosecuting an empirical science of the mind along Newtonian lines but both writers came to very different conclusions, especially on the relative importance of common sense and scepticism. ${ }^{9}$ H.F. Klemme observes that while Hume was a 'thoroughgoing empiricist' who held that judgement was based on feeling or ideas, Reid recoiled from the scepticism that he felt empiricism led to and rested instead on the existence of self-evident innate principles. The difference between both men was largely personal as Hume was motivated by a desire to make peace with the philosophical paradoxes that confronted and disturbed him while Reid was more confident as he believed in the providential order of the universe ${ }^{10}{ }^{1}$ In prosecuting a science of the mind, Scottish thinkers, in essence, were divided over method between Reid and the 'principles of Common Sense' and Hume and 'the way of ideas'. ${ }^{11}$ Significantly, McCosh defined the Scottish philosophy in terms of logic and perception and sided with Reid against Hume. According to McCosh, members of the Scottish school were Baconian and proceeded 'on the method of observation, professedly and really'; they employed 'selfconsciousness as the instrument of observation'; and on the basis of the evidence garnered, 'principles are reached which are prior to and independent of experience'. ${ }^{12}$

Second, this article also addresses the relationship between Presbyterian religion and the Scottish Philosophy. Historians of North America in the late eighteenth and early 
nineteenth centuries have demonstrated the relationship between Common Sense philosophy and evangelical religion. This can be observed in a number of areas, including the distinction made between mind and matter, an attachment to democratic ideals, the similarity between the moral sense and conscience, and a commitment to the methodology of induction. ${ }^{13}$ Historians of Britain and Ireland have not been as explicit in noting this relationship though, as demonstrated below, it is obvious that Scottish thinkers such as Thomas Chalmers and John Abercrombie did use the epistemology of the Common Sense school to buttress the intellectual credibility of evangelicalism. Of course, there was a significant difference in religious outlook between nineteenth-century evangelicals and eighteenth-century Moderates, and Presbyterian evangelicals explicitly criticised the theology of Hutcheson. ${ }^{14}$ McCosh noted the tension between 'the Scottish philosophy and the Scottish theology' of Calvinism in the previous century. The former 'had magnified human nature, and tended to produce a legal, self-righteous spirit', while the latter 'humbled man and exalted God, enjoining such graces as faith, humility, and penitence'. Yet McCosh believed that 'there never was any real opposition between the facts gathered by the one and the truths taken out of God s Word by the other. The metaphysicians had shown that there is such a faculty in man as the conscience; and the conscience proclaims that man is a sinner, while the Bible provides a forgiveness for the sinner in a way which honours the moral law. ${ }^{, 15}$ Other evangelicals in the early nineteenth century were less sanguine. For instance, Ralph Wardlaw virtually dismissed the evidential value of moral philosophy in favour of the all-sufficiency of revelation. ${ }^{16}$ Both emphases were present in nineteenth-century Ulster, though McCosh's interpretation was the most popular.

The relationship that developed between evangelicalism and the Scottish philosophy points to a third important theme addressed in this article, the adoption and adaptation of Scottish Enlightenment thought after 1790. Crucial in terms of promoting the evangelical appropriation of Common Sense was Dugald Stewart whose textbooks turned Reid's ideas into a teachable philosophy that could be used 'as an apologia for any form of religious belief', 'to combat any form of scepticism', and to cultivate individual critical analysis by comparing ideas with 'the cannons of common sense'. ${ }^{17}$ Yet at the very time Common Sense was becoming widely adopted by evangelicals, Scottish philosophers such as James Mylne, Thomas Brown, and James Mill were questioning Reid's legacy. Mylne and Brown were influenced by French sensationalists, especially Étienne Bonnot de Condillac, and the British emphasis on the association of ideas. As James Harris reminds us, 'the philosophy of Common Sense never attained the status of dogma in Scotland. At both Glasgow and Edinburgh it was quickly subject to severe critical scrutiny. ${ }^{18}$ Stewart's successor at Edinburgh, Thomas Brown, was one of the leading intellectuals of early nineteenth-century Britain and his importance lies in the fact that his 'thought provided a bridge between the 
Scottish school of "Common Sense" associated with Thomas Reid, and the later positivism of John Stuart Mill and others'. ${ }^{19}$

The various tensions within Scottish philosophy noted above were illustrated in all their complexity during the public debates between Presbyterians over moral philosophy in early nineteenth-century Belfast. This article begins by examining the development to 1830 of the teaching of philosophy at the Belfast Institution against the backdrop of the growth of evangelicalism. The second and third sections offer an analysis of the two phases of the Ferrie controversy in 1829-1833 and 1834-1835.

I. Irrespective of which of the six Presbyterian groupings they were connected with, Irish Presbyterian ministers in the eighteenth century received their liberal arts education in Scotland and usually at the University of Glasgow. ${ }^{20}$ Glasgow was at the forefront of the Scottish Enlightenment and moral philosophy, as taught by Francis Hutcheson, Adam Smith, and Thomas Reid, became the most popular subject taken Presbyterian students from Ireland. McCosh noted this common college curriculum and that the 'inductive psychology ... allowed the students to follow their own convictions, evangelical or rationalistic, but training all to a habit of skilful arrangement and exposition' ${ }^{21}$ In addition, McCosh argued that eighteenth-century Scottish moral philosophers laid the basis for nineteenth-century evangelicals by using induction to establish 'a body of ethical truth on grounds independent of revealed religion', which could then be used to defend Christianity and point to the human dilemma that could only be met by revelation. ${ }^{22}$ Yet three general points are worth making about this eighteenth-century background. First, it is important not to overestimate the influence of lecturers on their students, and it is probably the case that student minsters were more affected by the theological outlook of the local presbytery who had responsibility for their training. ${ }^{23}$ Second, conservative Presbyterians were wary of the limits of moral philosophy. In his Dialogues, between students at the college (1782), John Rogers, the professor of theology for the Burgher Seceders in Ireland, noted that to 'a lad of good principles, that class may be very useful but I assert, that to a lad of no principles, the Moral Philosophy class is a very dangerous one', because it talked of 'moral virtues' but did not tell students that 'the true root of morality is love to God and man, and union to Jesus'. Though some would object that this was to teach divinity, Rogers noted that the majority of students in the moral philosophy class at Glasgow were would-be ministers and, as a consequence, 'it is no wonder, that their sermons have a greater similitude to the writings of the heathen philosophers, than to the writings of the prophets and apostles'. ${ }^{24}$ Third, despite these misgivings, evangelicals shared in the rhetoric and principles of the Enlightenment. This was especially so in the late eighteenth century owing to their involvement in missionary activity 
and its concern with the Enlightenment values of a common humanity, progress, improvement, pragmatism, and education. ${ }^{25}$

The foundation of Belfast Academical Institution in 1811 reflected the growing economic importance of Belfast and the desire of its middle-class citizens to cultivate higher culture and useful learning. It had the support of the political establishment, though the 'main impetus' came from those associated with political reform and radicalism. ${ }^{26}$ The college department of 'Inst' was opened in 1815 to provide a liberal arts education on a non-sectarian basis. The Board of Management also recognised that northern Presbyterians were the principle source of students as that community had long desired a home education for their trainee ministers. The Board suggested that the various Presbyterian bodies should appoint their own theological professors who would be permitted to teach on the premises and sit on the faculty. Despite government withdrawing funding from the Institution in 1817 owing to alleged disloyalty amongst the proprietors, the two main Presbyterian bodies appointed theological professors - Samuel Edgar for the Seceders and Samuel Hanna for the Synod of Ulster.

The Institution received widespread support from the protestant population of Ulster, but in the early 1820s there developed tensions between some orthodox Presbyterians and Inst over the influence of professors who held anti-Trinitarian views. ${ }^{27}$ This concern was fuelled by the rise of evangelicalism more generally in the North Atlantic world in reaction to the upheavals of the 1790s. ${ }^{28}$ At the heart of the movement was the individual's relationship with Christ that began with personal conversion. For that to be efficacious, Christ had to be fully divine - without diluting his full humanity - as an individual's salvation depended solely upon their personal relationship with him. The problem was that this view was increasingly challenged in the 1820s by a handful of prominent Arians, including William Bruce junior who in 1821 was elected to the chair of Latin, Greek, and Hebrew in Inst. The concern expressed by orthodox Presbyterians at Bruce’s appointment led the Faculty in February 1822 to adopt a pledge not to interfere with the religious principles of their students. ${ }^{29}$ This satisfied most conservative Presbyterians, including the Seceders, but Henry Cooke was not placated by this pledge and used his position as moderator of the Synod of Ulster in 1824-5 to continue his opposition to Arian influence at Inst. Before a select committee of the House of Lords he claimed that the college was in danger of becoming 'a great seminary of Arianism', though his notorious claim was widely challenged. ${ }^{30}$ Indeed, another official inquiry into the state of Irish education demonstrated that the foundation of Inst was an important means of encouraging the resurgence of Presbyterian evangelicalism as both Hanna and Edgar were Calvinists and active supporters of evangelical missionary societies. ${ }^{31}$

Philosophy was taught at Inst by William Cairns, the professor of logic and belleslettres, and John Young, professor of metaphysics and moral philosophy. Young and Cairns 
had much in common and both were included by McCosh in his Scottish Philosophy. ${ }^{32}$ Both were Seceders from Scotland, evangelical in their religious convictions, and from a middleclass commercial background. Young was born in Glasgow in 1781 to a hosier father. He was 'educated with a special view to his commercial prospects' and eventually entered Glasgow University in 1808 at the age of $27 .{ }^{33}$ Cairns had already graduated from Glasgow by the time Young had matriculated and was Seceder minister at Johnshaven, near Montrose, between 1808 and 1815, and had preached 'with much acceptance' in Dublin in the summer of $1805 .{ }^{34}$ Both received their philosophical training at Glasgow from George Jardine and James Mylne. After their appointment to the Institution in 1815, they quickly became fixtures of the cultural and intellectual life of Belfast. Like their colleague James Thomson, professor of mathematics and father of Lord Kelvin, Cairns and Young were politically-liberal evangelicals who were committed to the non-sectarian ideals of the Institution. ${ }^{35}$ The obituary of Cairns in the Northern Whig was clear on this point: 'To a fervent piety, and a sincere attachment to his own religious opinions, he united perfect toleration and charity towards those who differed from him. ${ }^{36}$

Yet the religious convictions of both men were obvious in their public careers and did influence the curriculum they offered. Cairns 'took a lively interest in various religious and benevolent institutions' in Belfast and recognised his role in preparing students for ministry, including 'in his lectures disquisitions on hermeneutics, on the principles of interpretation, and on the authenticity and truth of the Sacred Scriptures, a discussion upon miracles and upon reasoning from or to final causes'. ${ }^{37}$ Young 'referred, in all his speculations, to Him who is the fountain of truth; and cherished a habitual regard to the great principles of natural and revealed religion', and in life and on his deathbed 'retained a belief in those views of Christianity which are usually denominated evangelical'. ${ }^{38}$ In an interview with the Seceders in 1822, both professors entered their understanding that 'in all their instructions, and in conducting the discipline of the College, they will invariably recognise the truth and authority of natural and revealed religion, and will inculcate the general principles of Christian piety and morality'.39

In terms of their philosophical ideas and principles, both Cairns and Young were members of the Scottish school by education and were in the Common Sense tradition of Reid against Hume. Before the education inquiry in 1826, Cairns stated that the aim of his course was 'to introduce the students to an acquaintance with the elements of modern intellectual philosophy, so far as those apply to reasoning and scientific investigations of different kinds' ${ }^{40}$ There was no textbook but Cairns regularly referred to Reid, Dugald Stewart, Thomas Brown, and James Beattie, in addition to works on logic by Isaac Watts and William Duncan. He devoted considerable time to Locke, as well as Aristotle and Bacon's Novum Organum, and discussed Berkeley and Hume in order to refute their approach. It was 
generally agreed that Cairns lectures on philosophy were less impressive than those on belleslettres, which showed him 'in a much higher light' and were 'original, full, and accurate' ${ }^{41}$ Nevertheless, Cairns' obituary in the Banner of Ulster, the mouthpiece of Presbyterian evangelicalism, noted that his lectures 'abjured the metaphysic subtleties of continental sciolists, and imbued the minds committed to him with the philosophy of observation and common sense'. ${ }^{42}$ Cairns' publications confirmed his association with Common Sense. One estimation of his Outlines of Lectures on Logic and Belles-Lettres (1829; 1835; 1841) noted that his approach 'was not new-fangled with Kantian distinctions, nor Hegelian abstractions; it was a very thoroughly Scoto-common-sense course of lectures' that followed those of his own lecturer at Glasgow, George Jardine. ${ }^{43}$ His Treatise on Moral Freedom (1844) was broadly in the Common Sense tradition, though it never became widely known because, as noted by McCosh, 'It is not easy to give an analysis of it: in fact it is not easy to understand it. $^{44}$

The first section of Young's curriculum concentrated on 'what is called Intellectual Philosophy; the general phenomena of the human mind, such as sensation, memory, and judgement', with a special focus on the theories of Locke, Berkeley, Hume, Reid, and Stewart. ${ }^{45}$ Though he independently arrived at his three-fold classification of mental phenomena (sensation, memory, judgement), he had been beaten to publication by Thomas Brown and his posthumous Lectures on Intellectual Philosophy (1835) made little impact. ${ }^{46}$ During his evidence before the select committee in 1826, Young stated that given the subject matter covered in the moral philosophy course, a professor of Hume’s Deist principles would represent a serious danger to orthodox religion. He wanted his successor to be an orthodox Presbyterian in order to ensure public confidence as 'the great body of the people are Orthodox' ${ }^{47}$ Young's views were shared by Samuel Hanna who was adamant that it was not a matter of indifference whether or not a professor of moral philosophy held correct religious principles and conceded that the appointment of a person of unorthodox views might cause problems in the future. ${ }^{48}$ As it stood, both Cairns and Young were excellent choices - Cairns was 'a pious, excellent, worthy man', while Young attended Hanna’s Third Congregation in Belfast 'and is a very warm supporter of the same system of religious truth which I hold, Calvinism' ${ }^{49}$ Hanna expressed his dislike of Hume, an opinion that was widely shared by those who gave evidence, and admitted that he would prefer the chairs of logic and moral philosophy to be filled 'by persons of my own sentiments'. ${ }^{50}$ This concern was hypothetical because Young and Cairns were orthodox, but the appointment of Young's successor in 1829 caused significant and prolonged controversy. 
II.

John Young died on 9 March 1829 and was universally lamented by the citizens of Belfast. Eleven individuals applied for his vacant chair, though two frontrunners quickly emerged, James Carlile and John Ferrie. Carlile was something of a curiosity. He was a prominent evangelical and minister of Mary’s Abbey Synod of Ulster congregation in Dublin, but he was also a non-subscriber and the principal opponent of Henry Cooke in the 1830s in his position as one of the commissioners of the National Education system. ${ }^{51}$ Nevertheless, Carlile was the preferred candidate for both the Synod of Ulster and the Secession Synod. He was a significant author and published a Manual of the Anatomy and Physiology of the Human Mind (1851), which was very much in the Common Sense tradition. ${ }^{52}$ However, his letter of application noted his excitement at 'resuming an interesting course of inquiry and illustration which has long been in a great measure suspended'. His testimonials came from a variety of acquaintances of different denominational backgrounds, though none of them were noted philosophers. ${ }^{53}$ By contrast, the Revd John Ferrie was a minster of the Church of Scotland, chaplain at Glasgow University, would twice subscribe to the Westminster Confession of Faith, and had testimonials from some of the foremost philosophical writers of the day. ${ }^{54}$ Yet Ferrie's philosophy, discussed in detail below, was a departure from the Common Sense school. It was empirical and owed much to Thomas Brown as well as the physiological approach of David Hartley and the sensationalism and utilitarian ethics of James Mill. The election on 18 June 1829 saw Ferrie chosen by fifteen votes to thirteen. ${ }^{55}$

Ferrie's appointment at the expense of the candidate of the evangelicals caused immediate conflict as it coincided with the climax of the Arian controversy within the Synod of Ulster. ${ }^{56}$ His appointment was the subject of intense debate at the annual meeting of Synod in July 1829. Surprisingly, Carlile was one of the first to speak and he gave voice to his evident disappointment and criticised, in turn, the electors, Ferrie, and Glasgow University. According to Carlile, and Cooke, Ferrie was a 'new light' man proposed by Arians. Aside from his evident disappointment and personal trauma at the recent death of a young child, Carlile was concerned about what Ferrie would teach on the evidence presented in his testimonials: 'Not of heaven and hell, and eternity, and human responsibility, but of the powers of the human mind, and the principles of his favourite philosophy - topics exactly similar to those which are generally discussed in the Unitarian pulpits in this country. ${ }^{57}$ Despite a vigorous exchange between Cooke and his principal Arian opponent, Henry Montgomery, the Synod found that no breach of regulations had occurred in Ferrie's election. The matter was resumed at a special meeting of Synod in August and discussions with the Institution continued, though the matter was left to rest until 1834. In the meantime, a committee report to synod in 1830 confirmed Ferrie's attachment to the Westminster Confession and noted that the examination results of his students had established his 
pedagogical and academic competence. Yet they unanimously expressed their general concern with 'the ordinary system hitherto pursued in the teaching of Moral Philosophy' and wanted the Synod to consider a system 'more congenial to the views of our Students, as candidates for the sacred ministry' ${ }^{58}$

The concern expressed by the Synod was a product of resurgent evangelicalism, which reinforced the final authority of the Bible and the necessity of divine grace to save sinful humanity. For many evangelicals, philosophy was an unwanted distraction from the effort to save souls, but others sought to reconcile these theological principles to their intellectual environment and found in Thomas Chalmers a model for doing so. Chalmers was leader of the evangelical party in the Church of Scotland and the most influential British theological writer in the first half of the nineteenth century. According to McCosh, it was Chalmers who was responsible for reconciling the Scottish philosophy and the Scottish theology of Calvinism. ${ }^{59}$ For Chalmers, Common Sense philosophy provided a basis from which Christianisation could be achieved by removing doubts about the existence of God and by hinting at the human dilemma of sin that could be solved only by the atoning death of Christ and divine grace. Chalmers applied Baconian methods to natural theology and sought to replace Moderate theology with 'the science of revealed theology' in order to portray evangelicalism as rational and respectable to the Scottish middle classes. ${ }^{60}$ This commitment to Common Sense and the inductive method was lauded by Presbyterian evangelicals in Ireland, a number of whom had attended his lectures in theology at Edinburgh University. ${ }^{61}$

Other figures shared Chalmers concern to reintroduce the doctrines of sin and grace into philosophical discussion. Two in particular were cited by Presbyterian evangelicals throughout the Ferrie controversy - John Abercrombie and Ralph Wardlaw. Abercrombie was a medical doctor originally from Aberdeen who specialized in diseases of the brain and intestines. He was an ardent evangelical and joined Chalmers' Free Church when it was formed in May 1843. According to Thomas Dixon, Abercrombie's Inquiries Concerning the Intellectual Powers and the Investigation of Truth (1830) and The Philosophy of the Moral Feelings (1833) were 'among the most widely read British philosophy books in the middle of the nineteenth century' ${ }^{62}$ McCosh noted that the reasons for this popularity could be linked to Abercrombie's commitment to Common Sense, the apt illustrations he chose, and the fact that 'there runs through all his works a vein of evangelical piety, decisive and outspoken without being offensive' ${ }^{63}$ Ralph Wardlaw was an evangelical and Scottish Congregationalist who was for many years a professor of theology for his denomination. Wardlaw was a prolific author and a man of strong opinions. He was certainly outspoken in his dismissal of the value of moral philosophy in comparison with Chalmers and Abercrombie. Wardlaw's Man Responsible for his Belief (1825, 1827) and Christian Ethics (1833) asserted the supremacy 
and all-sufficiency of revelation as the only test of religious truth in comparison with human nature and natural religion. ${ }^{64}$

A lively debate between Ferrie and his opponents about the balance between reason and revelation, and the definition and character of the Scottish philosophy, was carried on in the Belfast News-Letter between July and October 1829. Carlile began the debate by criticising the usual way moral philosophy was taught and the need to ensure it accorded with revelation and the principles of divine grace. In the same terms used by Wardlaw, Carlile felt that the key weakness of the Scottish philosophy was confining the discussion solely to human nature without the data of biblical revelation, which clearly stated principles that ought to be taken into consideration when discussing ethics. For him, the religion fostered by moral philosophy was New Light, deism, and rational Christianity. ${ }^{65}$ Carlile was convinced - and cited John Young in his defence - that the 'light of nature' must be balanced by the light of revelation.

I however assure him that I would follow the light of nature as far as in point of fact it ever led any man towards the truth; that, without neglecting natural religion, I would endeavour to keep it in its own place; that I would endeavour to prove that there are duties which all men are bound to perform independently of oral or written revelation; that I have been in the frequent habit of adverting to an eternal standard of moral rectitude altogether independent of positive enactment; and yet that I should have regarded it as most "daring presumption" and impiety to propose to teach a system of morals, without availing myself of that aid which the author of our being has vouchsafed to us in his written word. ${ }^{66}$

In response to a letter from Henry Montgomery, Carlile stated that the writings of Reid, Stewart, and Thomas Brown he admired 'almost to enthusiasm', and regarded Brown's Analysis of the Human Mind, 'as one of the most finished works in the English language'. Yet he expressed his conviction 'that a man who makes no pretensions to their talents might teach morals better than any, or all of them, by availing himself of the aid of the Scriptures, which they rejected'. ${ }^{67}$

Apart from Montgomery, Carlile’s chief opponent wrote under the pseudonym John Knox Junior. ${ }^{68}$ Knox claimed that he held the 'same general views of divine truth' as Carlile and opposed the appointment of an Arian to those departments directly connected with ministerial education. Yet he wanted to defend truth against Carlile's erroneous opinions, vindicate Young and the eminent Christians who had laboured in Scottish colleges, and draw a distinction between moral philosophy and theology. In a manner similar to McCosh, he defended eighteenth-century Scottish philosophers who had upheld natural theology against Hume and who had laid the groundwork for conversion. 
Revelation was not given to tell us that there is a God - that man is a moral being, and that there are in actions the necessary distinctions of virtue and vice. It presupposes all these, and its very claims upon our acceptance are founded on that presumption. Take away from human nature these elements of natural belief, and you leave not behind even the wreck of a principle to which any revelation can address itself. Hutcheson, Reid, and their contemporaries had prepared the ground for Christianity by establishing the moral truths on which it depended. ${ }^{99}$

The debate over the teaching of moral philosophy and the legacy of Scottish philosophy continued in the pages of religious periodicals between July 1831 and February 1832, especially the Bible Christian, organ of the Remonstrants, and the Orthodox Presbyterian. Substantial criticism of Ferrie's teaching came from an unexpected source. The Revd Dr William Bruce wrote a series of letters for the Bible Christian under the pseudonym 'Erasmus' in response to special lectures delivered by Ferrie to women in Belfast in 1831. ${ }^{70}$ After Montgomery, Bruce was the most prominent Arian in Ireland, a prolific theological writer, and father of Professor Bruce in Belfast Inst. He had been taught philosophy by George Jardine and Thomas Reid at Glasgow in the 1770s and his Treatise on the Being and Attribute of God (1818) was based on Common Sense principles. ${ }^{71}$ In his unpublished papers there are two manuscript memorials to the managers of the Academical Institution in 1831-2. The first gave a cautious welcome to Ferrie's introduction of contemporary approaches, but the second, according to David Steers and M.A. Stewart, notes critically 'that Ferrie was presenting a consequentialist ethic that did not give due recognition to the moral instincts' ${ }^{72}$ These concerns were clearly expressed in Erasmus' 'Letters to a Literary Lady', the first of which was published in July 1831. Bruce traced the development of idealism from Plato, through Locke and Berkeley, to Hume. With evident relief, he stated that 'Reid broke the spell, released mankind from this delusion; and laid the foundation of philosophy on the basis of "common sense", the constitution of man, and the will of God. Here I am inclined to stop and take my abode. Let my soul dwell with common sense; for I foresee, that if I follow our new guides, they will lead us back to scepticism and fatalism. ${ }^{73}$ Reid's position was supported by Beattie and Stewart against Brown and Mill, and Bruce expressed his concern about the implications of Hume's idealism for morality and religion, as well as Mill's doctrine of cause and effect. Bruce argued that humans were 'supplied with Instincts, and Instinctive Principles and Propensities', the highest of which was the moral sense, as understood by Francis Hutcheson, which God had given humanity in order to discern the difference between right and wrong. ${ }^{74}$

Bruce's implication that Ferrie was in the tradition of Hume against that of Hutcheson and Reid drew forth a series of responses from Ferrie under the alias, 'A Student of Intellectual and Moral Science'. ${ }^{75}$ Ferrie claimed that Reid 'merely begged the question in 
dispute. He assumed what cannot be granted, with a view to disprove what cannot, when rightly apprehended, be denied. ${ }^{, 76}$ Ferrie criticised the use of the term 'Common Sense' as 'a phrase freely and frequently employed by all shallow thinkers’ and which he strongly suspected 'denotes in philosophy, what orthodox denotes in religion - the opinions of the most numerous party'. The principle he adopted in his teaching was to examine the evidence free from suppositions rather than rely on 'Common Sense', which led to dogmatism. In terms of the identity of the Scottish tradition, Ferrie claimed that there was little difference between Brown, Mill, Reid, Hartley, and Hume, except 'in arrangement and nomenclature'. He did observe that 'Reid's school, or that of instincts, stands no doubt almost alone', and though Dugald Stewart, 'by the lustre of his style will throw over it a protection that may serve to embalm it for a while ... nothing will save it from sinking sooner or later to the grave of oblivion'. ${ }^{77}$

The exchange in the Bible Christian soon attracted the attention of Presbyterian evangelicals. The Orthodox Presbyterian weighed into the debate as they were increasingly concerned about the character and content of ministerial education. The first contribution came from 'A Lover of True Philosophy' who offered a review of the discussion between Bruce and Ferrie. An editorial note that accompanied the letter stated that if the author was correct about 'the neological principles' of the 'Student', then the Synod of Ulster had to act. $^{78}$ The 'Lover of True Philosophy' dealt at the outset with Ferrie's claim that Reid merely begged the question. 'When Dr Reid takes for granted, that there are such objects as the senses testify, he does not beg the question, but demands the assent of his opponent as a rational being: if he refuses it, he turns away from him as a lunatic.' He also clarified Reid's appeal to Common Sense, which was 'not to the ignorant, in opposition to the learned; but to men in general, having an ordinary portion of understanding $\cdot{ }^{79}$ In his response, Ferrie defended his empirical approach to philosophy and was quick to denounce the antiintellectualism of evangelicals in general, characterising the argument of his opponent as a 'strange farrago of nonsense'. ${ }^{80}$ Ferrie in turn received savage criticism in the February 1832 issue of the Orthodox Presbyterian. ${ }^{81}$ The following month the 'Lover of True Philosophy' argued that the evidence of revelation ought to be considered in philosophical discussion. The author was prepared to consider philosophical charges against biblical teaching and would 'admit all her self-evident truths, and all her facts. But if she pretends to deduce from these any thing contrary to Scripture, I will tell her she must be mistaken; for that the God of nature cannot contradict the God of revelation. If Scripture is the word of God, it cannot be contradicted by evidence of any kind. ${ }^{82}$ This article marked the end of the first phase of the Ferrie controversy.

III. 
Presbyterian evangelicals continued to express their concern about college education in general and the mode of teaching moral philosophy in particular. The extent of the threat to the Synod of Ulster was obvious to one anonymous writer. The Synod had been 'mercifully delivered from the infection of the Arian heresy, but it yet needs to be delivered from the influence of a dangerous and deceitful philosophy. This is the more dangerous, as it is less startling, but more insinuating. We look upon it to be the most dangerous foe with which our church has at present to contend, and we will not fail to lift our warning voice against it as we shall have opportunity. ${ }^{83}$ This general unease once again crystallised around Ferrie in May 1834. The Seceders were the first to reopen the issue on 2 May when their Education Committee passed a resolution expressing their concern that attendance on the moral philosophy class, 'as at present constituted, is unfavourable to the preparation of students for the Christian Ministry', and reiterated their wholehearted attachment to the home education offered by the Institution. ${ }^{84}$ The committee's report was presented to a full meeting of synod by Robert Wilson, editor of the Christian Freeman and soon to be appointed professor of biblical criticism for the Seceders. Wilson identified three areas of concern with Ferrie's teaching - the denial 'of a separate thinking principle', the failure to recognise the authority and necessity of revelation, and utilitarian ethics. Wilson claimed that Ferrie 'taught that mind consists of sensations and ideas, or trains of consciousness, but that they are not manifestations of mind, or of a thinking principle, or, in fact, of the existence of such thing as a soul at all'. The effect of this was to deny the existence 'of a separate thinking principle', and as Ferrie was not definite in his explanation of his ideas, the tendency of his teaching was towards scepticism, especially belief in the immortality of the soul. An anonymous article entitled 'Moral Philosophy' in the September issue of the Christian Freeman reiterated the objections of the synod to the general approach to the teaching of moral philosophy. Such teaching overlooked the 'great fact' of revelation in Scripture and the 'fact' of human moral depravity. As a consequence, 'There must be a reform in the Moral Philosophy class in the Belfast Institution. Moral philosophy must be christianized. This and every other science must be baptized in the name of Christ. ${ }^{85}$

The Synod of Ulster appointed a committee to meet in October 1834 to discuss the matter. The Orthodox Presbyterian was keen to impress on the committee the need to consider the principles on which moral science was taught and referred to the 'light poured on this subject' by Abercrombie and Wardlaw. ${ }^{86}$ In August a review appeared of Wardlaw's Christian Ethics. It offered an enthusiastic estimation of the work as well as a protest against 'the arrogant assumption, that reason is competent to make a full discovery of the whole of human duty; and that the Scriptures must not be permitted to speak on these subjects' ${ }^{87}$ During three sessions in July and September 1834, the Synod's committee took evidence from sixteen students under their care who had attended Ferrie's class. The evidence collected 
showed that Ferrie did not interfere with the personal religious views of his students and many spoke positively of his instruction. However, there was a general concern with the tendency of Ferrie's teaching. According to Thomas Magee Morrow, there were four reasons why Ferrie's course was not suitable for trainee ministers: ' 1 , Because the introduction of the Scriptures is objected to; 2, Virtue made to consist in the consequences of an action without reference to the word of God; 3, The mind made to consist in sensations and ideas; and 4, man's accountability made to consist in his knowledge'. The report of the committee to Synod recommended that students should not attend the moral philosophy class because 'certain of the doctrines' taught by Ferrie were 'in their opinion, unfriendly to the authority of the Scriptures - calculated to foster a spirit of scepticism - at variance with several fundamental principles of the gospel - and unfavourable to the proper training of candidates for the ministry in our church' ${ }^{88}$

A special meeting of Synod in September 1834 accepted the report and drew up plans to provide alternative instruction. ${ }^{89}$ Cooke was appointed to lecture on ethics and natural theology while Henry Molyneux, the minister of Larne, would teach metaphysics. ${ }^{90}$ Copies of Wardlaw's Ethics and Brown's Philosophy of the Human Mind were provided out of class funds and sold at reduced prices to the students. James Carlile observed that Ferrie's curriculum 'was the same kind of system as that which existed in Scotland in many instances, and he was perfectly persuaded of its mischievous effect, from his own knowledge of the speculations about which it was conversant'. Most agreed with him on that point, but his suggestion that a committee of Synod draw up a statement of the teaching they expected in a moral philosophy class, which would then be presented to Ferrie, was rejected out of hand by Cooke who asked 'what necessity was there for wasting time about the utility of a philosophy, which avowedly could not tell whether man had a soul or not - which could not decide whether God was a material being, whether his existence should endure throughout all eternity, or whether he might not die to-morrow?' James Seaton Reid was keen to note 'the fundamental objections entertained by the Committee were the same as those advanced by the Seceders, relative to the confining of all human knowledge to consciousness, thus taking away all evidence of an external world, and the existence of God'.

While these discussions were taking place within the church courts, a keen debate was carried on in the local press, especially the Belfast News-Letter between 15 August and 26 September 1834. The statements of Ferrie and his supporters, especially Candidus in the Belfast Commercial Chronicle and 'G.G.' in the Northern Whig, confirmed Ferrie's sensationalism, utilitarian ethics, and empirical approach. G.G. defended Ferrie as the true Baconian and criticised his opponents for basing philosophy on first principles rather than 'upon indisputable facts, deduced from OBSERVATION AND EXPERIMENT' ${ }^{91}$ In an attempt to clarify the issue at stake, Ferrie in his ninth letter to the Belfast News-Letter stated 
that knowledge of the human mind was 'bounded by consciousness'. Wilson had conceded 'that "he is not desirous to go beyond consciousness", but adds, "I feel irresistibly impelled to view the phenomenon of consciousness as the phenomena of mind or of a thinking principle".' Ferrie claimed that this 'highly figurative statement' was the 'statement of a case of consciousness, and therefore, that the sole point controvertible between us relates to the elements of which it consists'. The question was, 'does the state of consciousness ... contain or not an IDEA of the MENTAL SUBSTANCE? Yes or no, is the only answer which can be received. ${ }^{92}$ In his fifth letter of a series of eight, Wilson also attempted to identify the main points at issue. Ferrie's doctrine of the constitution of the human mind was erroneous and at variance with orthodox doctrines. Quoting Reid, Stewart, and Brown in support, Wilson was adamant that 'all our sensations and ideas are to be referred to this thinking substance ... a first principle, or fundamental law of human belief', and challenged the professor to show upon what grounds he recognised the existence of the corporeal frame or the external world more generally. ${ }^{93}$

Another of Ferrie's opponents was James McKnight, editor of the Belfast News-Letter who 'far surpassed all his contemporaries, even Molyneux, in his knowledge of metaphysics' and 'was one of Professor Young's favourite pupils'. ${ }^{94}$ In a private letter to H.W. Molyneux dated 27 August 1834, James McKnight expressed his frustration that his position as editor precluded him from tearing apart Ferrie's system which, in his opinion, was 'a most detestable jumble of balderdash' in the same vein as the French atheist philosophers of the eighteenth century. McKnight also informed Molyneux that 'Ferrie tried by a most awful manoeuvre to commit me to a qualified expression of approval of his explanations, and when this did not succeed, he openly applied to me to advocate his cause editorially'. He refused to do so and was met with a torrent of abuse. McKnight wished that his correspondent had heard Ferrie's explanations, which reduced all states of consciousness to one consciousness and 'that our belief in our own mental identity is altogether the effect of association - in other words, is a real delusion!' 95 McKnight's general opinion on philosophy was expressed in a three-part review of Young's Lectures, which appeared in the Belfast News-letter in November 1834. His first review underlined the importance of intellectual philosophy as 'the very foundation of all morality and natural religion'. It was clear that McKnight defined the Scottish philosophy in the same terms as McCosh would in 1875, referring to 'the Scottish school of metaphysics, in opposition to the school of Hume, Hartley, Priestly \&c'. 'There is an ultimate point beyond which simplification cannot be pushed without disturbing the whole fabric of human knowledge; we must stop somewhere, and must take something or other for granted without previous demonstration or ulterior refining, and when we have arrived at a first principle, it is never judicious, while it is frequently unsafe, to push our analysis farther. ${ }^{96}$ McKnight's second article expressed his reticence at commenting on the Ferrie 
case, but that it was impossible to discuss Young's lectures without raising relevant issues. Having traced sensationalist philosophy through Nicolas Malebranche, Pierre Daniel Huet, Berkeley, and Hume, he came to Reid, Stewart, and Brown who had

successfully laboured to overthrow the formidable system, which had thus threatened to blot the material world and its author from the map of existence, and the main instrument which they employed was assertion of the ultimate authority which Dr Reid called "common sense"; but which his followers have, with more propriety denominated the "fundamental laws of belief", the truth of which the veriest sceptic who ever affected a doubt, must take for granted, even in the very act of doubting. This Common Sense school had been challenged by utilitarians, Condillac and the sensationalists, and well-meaning but badly informed religious writers such as Wardlaw, but it still 'laid the only foundation on which morality and religion of any kind can be established, in opposition to that withering philosophy which would plunge us into a vortex of universal doubtfulness in theory, and which would, in practice, resolve our holiest sympathies into a low, base, contemptible residuum of the meanest selfishness' ${ }^{97}$ McKnight's final article offered a lengthy discussion of Wardlaw's Christian Ethics, whose views, he noted, were shared by James Carlile. McKnight agreed with Wardlaw that human depravity ought to be discussed in ethics as it was a fact based on experimental evidence, as demonstrated by Jonathan Edwards, and that the authority of Scripture ought not to be set aside. Yet he also wanted to assert the importance of human reason and natural theology. 'The conclusions of unaided reason may be defective - they may fail of discovering many things which Christianity has "brought to light" - nay, they must do so if Christianity be a revelation at all; but then, so far as they go, there cannot, from the very nature of things, be a possibility of their establishing a solitary error in opposition to supernatural truth.' Wardlaw had gone much farther than Chalmers who in his Commercial Discourses (1820) warned against pushing the doctrine of human depravity too far in overturning the witness of conscience, while Edwards argued that depravity was a matter of the affections and the passions rather than the intellectual powers. McKnight concluded by pointing out that Wardlaw's views were also in opposition to those of John Calvin and Chapter 21 of the Westminster Confession of Faith, as well as being inconsistent with his own principles. ${ }^{98}$

The charge that Ferrie's views were similar if not identical to the atheistical philosophy of eighteenth-century France as well as British sensationalists was made in the Belfast News-Letter by ‘A Presbyterian’ whose analysis was the same as that offered by McKnight in his letter to Molyneux. ${ }^{99}$ The author was especially concerned to distinguish between the philosophical company kept by Ferrie and the Common Sense tradition. 'To persist day after day, in virtually asserting the identity of the school of Helevtius, Mirabeau, Priestley, Godwin, Jeremy Bentham, and Mill, with the school of Reid, Stewart, Brown, and 
Chalmers, is so monstrous as to excite the derision of every man in society who has the acquaintance with the works of the one class or the other.' 100 'A Presbyterian' also noted that scepticism in France was being overturned by Pierre Paul Royer-Collard and Victor Cousin who were employing the Scottish philosophy with its 'assumptions' and claimed that Kant's transcendentalism 'is, in reality, only a modification of the "assumptions" of the Scottish school, and that its direct object and tendency are the extirpation of the pernicious systems of materialism and irreligion’. ${ }^{101}$ This interpretation was challenged by ‘A True Presbyterian', who sided with Brown in his exposure of the assumptions of Stewart and Reid and pointed out that Kant was a sceptic who believed in the annihilation of the soul and that Cousin was a pantheist. ${ }^{102}$ After a month of almost daily letters on the topic, the Editor of the Belfast NewsLetter on 16 September stated that the 'controversy has now gone beyond all reasonable bounds, and, tedious as it has been, the parties seem to be as far as ever from bringing it to a conclusion'. He announced that any future letter on the topic would be charged as an advertisement. ${ }^{103}$

The combined pressure of the criticism offered by the orthodox Presbyterian bodies and the debate in the press forced the Board of Managers of the Institution to act. They set up their own inquiry into the teaching of moral philosophy that began on 4 December 1834 and ran for seventeen evenings at an average of six-hours per session. ${ }^{104}$ In total, 26 students were examined (7 of whom were re-examined), 13 connected with the Synod of Ulster, 5 Seceders, 2 Reformed Presbyterians, 4 Remonstrants, and 2 unconnected with any religious body. An elaborate and scrupulous system of questioning witnesses and recording evidence was instituted. The committee of inquiry were unwilling to offer a considered opinion on Ferrie's teaching, but a number of important themes emerged. There was a consensus that Ferrie did not interfere with the personal religious views of his students; that he was, generally speaking, even-handed in his discussion of disputed points; and that he was a necessitarian but not a materialist. In terms of the content of his curriculum, Ferrie examined students on Thomas Brown every Saturday and was greatly influenced by James Mill in his understanding of accountability and belief. The tendency of his teaching was considered by some detrimental to certain theological positions, including particular providence and human depravity. In terms of ethics, Ferrie's preference was for utility rather than the revealed will of God as the standard of virtue, though he refuted the theory of moral sense offered by Brown and Hutcheson. The majority of evidence collected on the study of the constitution of the mind showed that Ferrie denied the existence of a separate thinking principle and confirmed his refusal to go beyond the phenomena of consciousness and assume the existence of fundamental laws or intuitive principles of belief.

It is clear that the most forthright opposition to Ferrie came from students connected with the Synod of Ulster while Remonstrants were the most positive. Seceder and Reformed 
Presbyterian students tended to be more complimentary than those of the General Synod, though they were still critical of the tendency of Ferrie's curriculum. Those who criticised Ferrie's teaching usually offered a broader critique of the common mode of teaching moral philosophy and cited Wardlaw in support. James Glasgow claimed that Ferrie's lectures were detrimental to the doctrine of human depravity in the same way as some of the works of Reid, Brown, Berkley, Hume, and Stewart. It was Glasgow’s view that this doctrine was a 'philosophical fact' demonstrated by Edwards in The Freedom of the Will and by Wardlaw in Christian Ethics. ${ }^{105}$ It also emerged that there were two or three students, including Robert Blain and Samuel Simms, who did not agree with Ferrie and who read essays in class based on the Bible and / or Wardlaw's Ethics. According to Thomas Magee Morrow, Simms stopped reading his essay owing to the 'unpleasant' manner in which Ferrie responded to it, with the result that Simms 'went so far as to shed tears'. Morrow was quick to note that Ferrie did not prevent these students from expressing their views, though he was anxious to defend and commend his own. ${ }^{106}$ Durham Dunlop was more sympathetic to Ferrie's position, noting that the professor 'decidedly' avoided interfering in the religious opinions of the students and, indeed, did not challenge the obvious prejudices of some students, especially Blain whose essay stated 'that mental science was useless' ${ }^{107}$

Ferrie submitted a letter to the inquiry in February 1835 commenting upon the 'impartial' and 'kind' treatment he had received during the investigation and appealed to the mass of evidence in vindication of his character and teaching. ${ }^{108}$ He claimed that 'I have never uttered a sentiment which can, with any fairness, be interpreted as adverse to revealed religion, or indeed to the peculiar views of any sect of Christians'. He noted that those who objected to the general system of teaching moral philosophy would always disapprove of his course and wish to base such education exclusively on revelation. Yet this was not the view of most philosophers and he was employed 'to give lectures according to the plan followed in Scotland'. Ferrie claimed that he did not 'slavishly' follow any writer, but noted the importance to him of Hartley, Brown, and James Mill. He concluded with a strong argument in his defence: 'What motive can I possibly have for teaching scientific error, or for attacking revealed truth? Is it likely that I should promulge publicly doctrines which, in my own private conduct, I practically reprobate? and who is there, at all acquainted with that conduct, who can step forward and charge me with either moral or religious delinquency?' 109

The inquiry found that the charges against Ferrie had not been substantiated, though the Board of Management made the offer of alternative instruction in moral philosophy under Cairns and Stevelly for the incoming session. The Synod of Ulster did not accept the suggestion and reiterated their demand that Ferrie should be replaced. The Institution resisted as Ferrie had not been found 'incompetent, negligent or immoral', though the Joint Board did not want to alienate the Synod and did everything short of dismissing Ferrie to placate 
them. ${ }^{110}$ One suggestion was to transfer him to a chair of political economy, but Ferrie refused to move and continued to teach moral philosophy to a small number of students until his retirement in 1849. The dispute between orthodox Presbyterians and the Institution entered its final phase in the early 1840s when the General Assembly of the Presbyterian Church in Ireland, formed in 1840 by the unification of the Seceders and the Synod of Ulster, decided to end the connection after two Arian professors of theology were appointed to Faculty. ${ }^{111}$

The disputes of the 1830s demonstrated that Presbyterian evangelicals by and large shared McCosh's definition of the Scottish philosophy. For the rest of the century, their commitment to Common Sense and the inductive method become indispensable to their apologetics, biblical interpretation, and understanding of natural science. ${ }^{112}$ During his time at Queen's College Belfast between 1851 and 1869, McCosh developed on the basis of Common Sense a form of 'intuitional realism' that 'constituted an attempt to provide a realist, but antimaterialist, account of human intuitions' ${ }^{113}$ It is obvious that the disputes over the teaching of philosophy at Belfast Academical Institution were not solely about Cooke’s ambition and cynical manipulation of Presbyterian evangelicals. The evidence presented demonstrates that philosophical principle was at stake. Moreover, this episode offers an opportunity to see how eighteenth-century Scottish philosophy fared in the early nineteenth century and how it interacted with the rise of evangelicalism. Though Common Sense was defended by theological liberals such as William Bruce, it was appropriated by evangelicals who attempted to 'Christianize' the Scottish Philosophy by showing the limits of natural theology. This common aim did mask differences of opinion over the precise balance between reason and revelation, with the more uncompromising voices favouring the relegation of moral philosophy along the lines suggested by Wardlaw. The philosophical debate was about who were the true heirs of the Scottish Philosophy, the followers of Hutcheson, Reid, and Stewart, or the supporters of Hume, Thomas Brown, and James Mill. Ironically, it was Presbyterian evangelicals who defended the tradition founded by the New Light Francis Hutcheson against those who sought instead 'the way of ideas'. 
* The author would like to thank David Livingstone, Diarmid Finnegan, Colin Kidd and the two anonymous readers for their valuable comments on an earlier version of this article. The author alone is responsible for the interpretation offered and the accuracy of the material presented.

${ }^{1}$ Michael Brown, ‘Hutcheson, Francis’, Dictionary of Irish Biography (Cambridge, 2009);

T.D. Campbell, 'Francis Hutcheson: “father” of the Scottish Enlightenment', in The Origins and Nature of the Scottish Enlightenment, edited by R.H. Campbell and A.S. Skinner (Edinburgh, 1982), 167-85; I.R. McBride, 'The School of Virtue: Francis Hutcheson, Irish Presbyterians and the Scottish Enlightenment', in Political Thought in Ireland Since the Seventeenth Century, edited by D.G. Boyce, Robert Eccleshall and Vincent Geoghegan (London, 1993), 71-99.

${ }^{2}$ J. D. Hoeveler, James McCosh and the Scottish Intellectual Tradition from Glasgow to Princeton (Princeton, 1981); D.N. Livingstone, 'James McCosh and the Scottish Intellectual Tradition', in Queen's Thinkers: Essays on the Intellectual Heritage of a University, edited by Alvin Jackson and D.N. Livingstone (Belfast, 2008), 19-30; W.D. Patton, 'James McCosh: The Making of a Reputation ...' (Queen's University Belfast, Ph.D. thesis, 1993).

${ }^{3}$ By far the best discussion of these themes is I.R. McBride, Scripture Politics: Ulster Presbyterians and Irish Radicalism in the Late Eighteenth Century (Oxford,1998).

${ }^{4}$ N.C. Landsman, 'Presbyterians and Provincial Society: The Evangelical Enlightenment in the West of Scotland, 1740-1775', in Sociability and Society in Eighteenth Century Scotland, edited by John Dwyer and R.B. Sher (Edinburgh, 1991), 194-209; J.R. McIntosh, Church and Theology in Enlightenment Scotland: The Popular Party, 1740-1800 (East Linton, 1998);

Gideon Mailer, ‘Nehemias (Scotus) Americanus : Enlightenment and Religion between Scotland and America', Historical Journal, 54 (2011), 241-264; J.M. Yeager, Enlightened Evangelicalism: The Life and Thought of John Erskine (New York, 2011).

${ }^{5}$ John Jamieson, The History of The Royal Belfast Academical Institution 1810-1960 (Belfast, 1959); J.M. Barkley, 'The Arian Schism in Ireland, 1830', in Schism, Heresy and Religious Protest, Studies in Church History 9, edited by Derek Baker (Oxford, 1972), 323-39; Crosbie Smith and N. M. Wise, Energy and Empire: A Biographical Study of Lord Kelvin (Cambridge, 1989), 11-12.

${ }^{6}$ The standard biography offers the most reliable and balanced discussion of Cooke's public career: R.F.G. Holmes, Henry Cooke (Belfast, 1981).

${ }^{7}$ Alexander Broadie, A History of Scottish Philosophy (Edinburgh, 2009); Gordon Graham, 'The Scottish Tradition in Philosophy', Aberdeen University Review, 58 (1999), 1-12. 
${ }^{8}$ Gordon Graham, 'The Nineteenth-Century Aftermath', in The Cambridge Companion to the Scottish Enlightenment, edited by Alexander Broadie (Cambridge, 2003), 338-50.

${ }^{9}$ Alexander Broadie, 'The Human Mind and its Powers' and Paul Wood, 'Science in the Scottish Enlightenment', in Broadie, Cambridge Companion, 60-78, 94-116.

${ }^{10}$ H.F. Klemme, 'Scepticism and Common Sense', in Broadie, Cambridge Companion, 11735, esp. 132.

${ }^{11}$ Gordon Graham, 'The Decline of Common Sense and the Rise of Scottish idealism', Rivista Di Filosofia Neo-Scolastica, 95 (2003), 39.

${ }^{12}$ James McCosh, The Scottish Philosophy, Biographical, Expository, Critical. From Hutcheson to Hamilton (London, 1875), 1-11. For a discussion of McCosh's reasons for writing this work, see James Somerville, 'The Trojan Horse of the Scottish Philosophy', Philosophy, 82 (2007), 235-57.

${ }^{13}$ Michael Gauvreau, 'The Empire of Evangelicalism: Varieties of Common Sense in Scotland, Canada, and the United States', in Evangelicalism: Comparative Studies of Popular Protestantism in North America, the British Isles, and Beyond, 1700-1990, edited by M.A. Noll, D.W. Bebbington, and G.A. Rawlyk (Oxford, 1994), 219-52; M.A. Noll, America's God: From Jonathan Edwards to Abraham Lincoln (New York, 2002), 93-113.

${ }^{14}$ J.S. Reid, History of the Presbyterian Church in Ireland, ed. W. D. Killen, 3 vols. 2nd edn. (Belfast, 1867), III, 296-9; McCosh, Scottish Philosophy, 84-86.

${ }^{15}$ McCosh, Scottish Philosophy, 393.

${ }^{16}$ W.L. Alexander, Memoirs of the Life and Writings of Ralph Wardlaw, D.D. (Edinburgh, 1856), 241-51, 327-34.

${ }^{17}$ Nicholas Phillipson, 'The Pursuit of Virtue in Scottish University Education: Dugald Stewart and Scottish Moral Philosophy in the Enlightenment', in Universities, Society, and the Future, edited by Nicholas Phillipson (Edinburgh, 1983), 99.

${ }^{18}$ J.A. Harris, 'Mylne, James', in The Continuum Encyclopaedia of British Philosophy, edited by Anthony Grayling, Andrew Pyle and Naomi Goulder (Bristol, 2006), III, 2293.

${ }^{19}$ Thomas Dixon (ed.), Thomas Brown: Selected Philosophical Writings (Exeter, 2010), 1.

${ }^{20}$ I. M. Bishop, 'The Education of Ulster Students at Glasgow University in the Eighteenth Century’ (Queen’s University Belfast, M.A. dissertation, 1987); W.I.P. Hazlett, 'Students at Glasgow University from 1747 to 1768 Connected with Ireland: An Analytical Probe', in Ebb and Flow: Essays in Church History in Honour of R. Finlay G. Holmes, edited by W.D. Patton (Belfast, 2002), 20-49.

${ }^{21}$ McCosh, Scottish Philosophy, 268.

${ }^{22}$ McCosh, Scottish Philosophy, 299-300. 
${ }^{23}$ A.R. Holmes, The Shaping of Ulster Presbyterian Belief and Practice 1770-1840 (Oxford, 2006), 135-42.

${ }^{24}$ John Rogers, Dialogues, Between Students at the College; Which Contain a Defence of the Leading Doctrines of Christianity: Also Shewing their Tendency to Promote Holiness; Interspersed with Philosophical Observations (Monaghan, 1782), 24-25.

${ }^{25}$ Brian Stanley (ed.), Christian Missions and the Enlightenment (Grand Rapids, Mich. 2001); A.R. Holmes, 'The Shaping of Irish Presbyterian Attitudes to Mission, 1790-1840', Journal of Ecclesiastical History, 57 (2006), 711-37.

${ }^{26}$ Peter Brooke, 'Controversies in Ulster Presbyterianism, 1790-1836', (University of Cambridge, Ph.D. thesis, 1980), ch.4; Robert Allen, The Presbyterian College Belfast 18531953 (Belfast, 1954), 37-54.

${ }^{27}$ The best and fullest accounts of relations between the Synod of Ulster and the Academcial Institution are Holmes, Henry Cooke, 31-46, 68-73, 125-8 and R.J. Rodgers, 'James Carlile, 1784-1854’ (Queen’s University Belfast, Ph.D. thesis, 1973), 78-152.

${ }^{28}$ M.A. Noll, 'Revolution and the Rise of Evangelical Social Influence in North Atlantic Societies', in Noll, Bebbington, and Rawlyk, Evangelicalism, 113-36.

${ }^{29}$ Fourth Report of the Commissioners of Irish education inquiry, HC (1826-7), xiii.157., 11

${ }^{30}$ Minutes of Evidence Taken Before the Select Committee of the House of Lords, Appointed to Inquire into the State of Ireland ... HC (1825) ix.1, 219; Rodgers, 'James Carlile', 89.

${ }^{31}$ Fourth report (1826-7), 49, 61-62, 93, 131, 136-37.

${ }^{32}$ McCosh, Scottish philosophy, 367-69, 369-70. Further biographical details may be found in 'Modern Logicians. William Cairns, LL.D., Late Professor of Logic and Belles-Lettres in Belfast College', The British Controversialist and Literary Magazine (1865), 241-52; 'Toiling Upward. John Young, LL.D.', The British Controversialist and Literary Magazine (1866), 376-84; John Young, Lectures on Intellectual Philosophy ... With a Memoir of the Author, ed. William Cairns (Glasgow, 1835), xv-xxxii.

33 'Toiling Upward', 377.

34 'Modern Logicians', 244.

${ }^{35}$ A.R. Holmes, 'Professor James Thomson senior and Lord Kelvin: Religion and Politics in Ulster and Scotland', Journal of British Studies, 50 (2011), 100-24, esp. 105-17.

${ }^{36}$ Northern Whig, 25 April 1848. See also Banner of Ulster, 25 April 1848.

37 'Modern Logicians', 249, 251.

${ }^{38}$ Cairns, 'Memoir' in Young, Lectures, xxxi.

${ }^{39}$ Fourth Report, 11.

${ }^{40}$ Fourth Report, 54.

41 'Modern Logicians', 249. See also Northern Whig, 25 April 1848. 
${ }^{42}$ Banner of Ulster, 25 April 1848.

43 'Modern Logicians', 247.

${ }^{44}$ McCosh, Scottish Philosophy, 370.

${ }^{45}$ Fourth Report, 103.

${ }^{46}$ Cairns, 'Memoir' in Young, Lectures, xi-xii.

${ }^{47}$ Fourth Report, 103.

${ }^{48}$ Fourth Report, 63.

${ }^{49}$ Fourth Report, 63.

${ }^{50}$ Fourth Report, 66-67. For expressions of opposition to Hume from other witnesses see, 121, 129.

${ }^{51}$ Rodgers, 'James Carlile’.

52 James Carlile, Manual of the Anatomy and Physiology of the Human Mind (London, 1851).

${ }^{53}$ Cited in Rodgers, 'James Carlile’, 116. His testimonials are discussed at 116-17.

${ }^{54}$ A.D.G. Steers, 'Ferrie, John’, in Grayling et al, Continuum Encyclopaedia, II, 1081-83.

${ }^{55}$ Rodgers, 'James Carlile’, 120.

${ }^{56}$ Holmes, Henry Cooke, 47-80.

${ }^{57}$ Belfast News-Letter, 7 July 1829.

${ }^{58}$ Minutes of a General Synod, held at Omagh, 1830 (Belfast, 1830), 32-33.

${ }^{59}$ McCosh, Scottish Philosophy, 393.

${ }^{60}$ D.F. Rice, 'Natural Theology and the Scottish philosophy in the Thought of Thomas

Chalmers', Scottish Journal of Theology, 24 (1971), 23-46; J.R. Topham, 'Science, Natural

Theology, and Evangelicalism in Early Nineteenth Century Scotland: Thomas Chalmers and the Evidence Controversy', in Evangelicals and Science in Historical Perspective, edited by D.N. Livingstone, D.G. Hart, and M.A. Noll (New York, 1998), 142-74.

${ }^{61}$ A.R. Holmes, 'Presbyterians and Science in the North of Ireland Before 1874', British Journal of the History of Science, 41 (2008), 541-65, esp. 551-3.

${ }^{62}$ Thomas Dixon, 'Abercrombie, John', in Grayling et al, Continuum Encyclopaedia, I, 5-8, 6.

${ }^{63}$ McCosh, Scottish Philosophy, 406.

${ }^{64}$ M.A. Stewart, 'Wardlaw, Ralph’, in Grayling et al, Continuum Encyclopaedia, IV, 3324.

${ }^{65}$ Belfast News-Letter, 7, 11 August 1829.

${ }^{66}$ Belfast News-Letter, 1 September 1829.

${ }^{67}$ Belfast News-Letter, 13 October 1829.

${ }^{68}$ The Revd D.G. Brown of Newtownhamiltion wrote under this pseudonym when criticising Cooke's politics in the mid 1830s, though Brown was a supporter of his during the Arian Controversy (Homes, Henry Cooke, 116). 
${ }^{69}$ Belfast News-Letter, 14 August 1829.

${ }^{70}$ Bruce's obituary in the Bible Christian noted that during this period he contributed reviews under the pseudonyms 'Erasmus’ and 'Nemo' (Bible Christian, ser. 3, 3 (April 1841), 119). His authorship is further corroborated by the similarity between the views of 'Erasmus' and the memorials sent by Bruce to the Institution in 1831-2 (see FN72 below).

${ }^{71}$ William Bruce, A Treatise on the Being and Attributes of God: With an Appendix on the Immateriality of the Soul (Belfast, 1818).

${ }^{72}$ A.D.G. Steers and M.A. Stewart, 'Bruce, William', in Dictionary of Irish Philosophers, edited by Thomas Duddy (Bristol, 2004), 43.

${ }^{73}$ Erasmus, 'A Letter to a Literary Lady’, Bible Christian, 2 (July 1831), 241-50, 244.

${ }^{74}$ Erasmus, 'A Letter to a Literary Lady', (July 1831), 249. Bruce offered an extended discussion of moral sense in a subsequent article: Erasmus, 'Third Letter to a Literary Lady', Bible Christian, 2 (October 1831), 369-77.

${ }^{75}$ Ferrie's identity as the author of articles in the Bible Christian and the Orthodox Presbyterian as 'A Student of Intellectual and Moral Science' was widely believed. See A Lover of True Philosophy, 'Philosophical Education. Remarks on Some Modern Doctrines of Metaphysics and Moral Philosophy, Occasioned by a Review of the Letters of “Erasmus”, by “A student” etc.', Orthodox Presbyterian, 3 (December 1831), 84; 'A Letter on Professor Ferrie’s Case’, Bible Christian, n.s. 2 (December 1837), 362; Robert Wilson in Belfast NewsLetter, 12 September 1834.

${ }^{76}$ A Student of Intellectual and Moral Science, 'Review of “A Letter to a Literary Lady”', Bible Christian, 2 (September 1831), 345.

${ }^{77}$ A Student, 'Review of “A Letter to a Literary Lady”, (September 1831), 346-7.

${ }^{78}$ A Lover of True Philosophy, 'Philosophical Education', (December 1831), 83.

${ }^{79}$ A Lover of True Philosophy, 'Philosophical Education’ (December 1831), 86.

${ }^{80}$ A Student of Moral Philosophy, 'Reply to “A Lover of True Philosophy”, Orthodox Presbyterian, 3 (January 1832), 133.

${ }^{81}$ Ne Sutor Ultra Crepidam, ‘Advice to A Student of Moral Philosophy’, Orthodox Presbyterian, 3 (February 1832), 169-71; A Lover of True Philosophy, 'Philosophical Education', Orthodox Presbyterian, 3 (February 1832), 171-80.

${ }^{82}$ A Lover of True Philosophy, 'Philosophical Education', Orthodox Presbyterian, 3 (March 1832), 204-08, 206.

83 'The Synod of Ulster', Orthodox Presbyterian, 4 (July 1833), 346.

${ }^{84}$ The following discussion is based on the public report of the meeting of Synod in the Belfast News-Letter, 8 August 1834.

85 'Moral Philosophy', Christian Freeman, 2 (September 1834), 382-4, 383. 
86 'The General Synod of Ulster', Orthodox Presbyterian, 5 (July 1834), 346-49, quotation 349.

87 'Christian Ethics’, Orthodox Presbyterian, 5 (August 1834), 379.

${ }^{88}$ Minutes of Evidence Taken in the Months of July and September,1834, Before a Committee of the General Synod of Ulster, Respecting the Teachings of the Moral Philosophy Class in the Belfast Royal Academical Institution (Belfast, 1835), 8, 17.

${ }^{89}$ The following paragraph is based on the report of the meeting of Synod in Belfast NewsLetter, 3 October 1834.

${ }^{90}$ H.W. Molyneux's approach to the teaching of philosophy may be found in his, The Philosophy of the Human Mind, an Essential Branch of the Professional Education of Teachers: Being a Lecture Delivered to the Ulster Teacher's Association, on Friday, the 26th January, 1844 (Belfast, 1844).

${ }^{91}$ Northern Whig, 1 September 1834.

${ }^{92}$ Belfast News-Letter, 16 September 1834

${ }^{93}$ Belfast News-Letter, 2 September 1834.

${ }^{94}$ Thomas Croskery and Thomas Witherow, Life of the Rev. A. P. Goudy, D. D. (Dublin, 1887), $25 n$.

${ }^{95}$ James McKnight to H.W. Molyneux, 27 August 1834 (Presbyterian Historical Society of Ireland, Molyneux papers).

${ }^{96}$ Belfast News-Letter, 7 November 1834.

${ }^{97}$ Belfast News-Letter, 11 November 1834.

${ }^{98}$ Belfast News-Letter, 14 November 1834.

${ }^{99}$ Belfast News-Letter, 5 and 12 September 1834.

${ }^{100}$ Belfast News-Letter, 26 September 1834.

${ }^{101}$ Belfast News-Letter, 12 September 1834.

${ }^{102}$ Belfast News-Letter, 19 September 1834.

${ }^{103}$ Belfast News-Letter, 16 September 1834.

${ }^{104}$ Minutes of an Inquiry Taken Before a Committee of the Joint Board of Managers and Visitors of the Royal Belfast Academical Institution, Respecting the Moral Philosophy Class (Belfast, 1835).

${ }^{105}$ Minutes of an Inquiry (1835), 17.

${ }^{106}$ Minutes of an Inquiry (1835), 92.

${ }^{107}$ Minutes of an Inquiry (1835), 125-6

${ }^{108}$ Minutes of an Inquiry (1835), Appendix, 69-71

${ }^{109}$ Minutes of an Inquiry (1835), Appendix, 70

${ }^{110}$ Rodgers, 'James Carlile’, 149. 
${ }^{111}$ Holmes, Henry Cooke, 68-73, 125-28; Rodgers, 'James Carlile’, 148-51

${ }^{112}$ A.R. Holmes, 'The Common Sense Bible: Irish Presbyterians, Samuel Davidson, and Biblical Criticism, c. 1800 to 1865’, in Scott Mandelbrote and Michael Ledger-Lomas (eds.), Dissent and the Bible in Britain, 1650-1950 (Oxford, 2013), 176-204; Holmes, 'Presbyterians and science'.

${ }^{113}$ Livingstone, 'James McCosh’, 23. Hoeveler, James McCosh, 112-46. 